\title{
Gugatan Konvensi Dan Rekonvensi Dalam Bingkai Syariat Islam (Analisis Putusan Nomor: 603/Pdt.G/2019/PA.Bm.)
}

\section{Convention And Reconvention Actions In The Framework Of Islamic Sharia (Decision Analysis Number: 603/Pdt.G/2019/PA.Bm.)}

\author{
Iksan \\ STIH Muhammadiyah Bima \\ (iksan687@gmail.com) \\ Adnan \\ STIH Muhammadiyah Bima \\ (adnan@stihm-bima.ac.id)
}

Abstrak: Putusan Pengadilan Agama yang berkaitan dengan perceraian merupakan produk hukum yang menjadi landasan bagi pihak yang berperkara untuk dilaksanakan dan dipatuhi. Namun terkadang, ada beberapa putusan yang tidak mencerminkan keadilan bagi sebagian pihak. Untuk itulah, peneliti mencoba menganalisis putusan Nomor 603/Pdt.G/2019/PA.Bm. terkait dengan perkara perceraian. Dalam analisis ini tentu didasarkan pada peraturan yang berlaku dan akan penulis komparasikan dengan hukum syariat (pendapat para ulama) terkait dengan permasalahan yang dalam putusan tersebut. Jenis Penelitian yang penulis gunakan adalah penelitian hukum Yuridis/Normatif dengan menggunakan pendekatan perundang-undangan. Pengumpulan dilakukan dengan menggunakan kepustakaan atau tulisan-tulisan yang relevan. Ada 4 hal yang menjadi materi gugatan rekonvensinya yaitu Nafkah Madiyah, nafkah Iddah, Nafkah Mut ah dan harta bersama. Berdasarkan pada hasil analisis putusan tersebut, penulis menarik kesimpulan bahwa putusan Pengadilan Agama Bima berkaitan dengan kasus gugatan perceraian konvensi/rekonvensi dengan Nomor Putusan 603/Pdt.G/2019/PA.Bm. masih belum sesuai dengan ketentuan syariat islam.

Kata Kunci: Keputusan, konvensi, rekonstruksi, hukum Islam 
Abstract: Decisions of the Religious Courts relating to divorce are legal products that form the basis for litigants to be implemented and obeyed. But sometimes, there are decisions that do not reflect justice for some parties. For this reason, researchers tried to analyze the decision Number 603/Pdt.G/2019/PA.Bm. related to divorce cases. In this analysis, of course, it is based on the applicable regulations and the author will compare it with sharia law (the opinion of the scholars) related to the problems in the decision. The type of research that the author uses is legal research / normative using a statutory approach. The collection is carried out using relevant literature or writings. There are 4 things that become the material for his reconsideration lawsuit, namely Madiyah livelihood, Iddah livelihood, Mut'ah livelihood and joint assets. Based on the results of the analysis of the decision, the authors conclude that the Bima Religious Court's decision is related to the convention / reconvention divorce case with Decision Number 603/Pdt.G/2019/PA.Bm. still not in accordance with the provisions of Islamic law.

Keywords: Decisions, convention, reconvention, Islamic law

\section{PENDAHULUAN}

Pengadilan agama merupakan salah satu lembaga peradilan Negara yang diberi kewenangan oleh undang-undang untuk mengadili kasus keperdataan islam seperti perkawinan, perceraian, hibah, waris dan lain sebagainya. Dalam proses pengambilan keputusannya pengadilan agama terkadang mengeluarkan keputusan yang tidak bisa memuaskan semua pihak. Kasus gugatan perceraian misalnya juga tidak lepas dari kecendrungan keputusan tersebut. Keputusan hakim dalam pertimbangannya di rasa tidak memiliki rasa keadilan bagi pihak yang merasa dirugikan.

Hal inilah yang mengilhami penulis untuk menganalisis hasil putusan yang dikeluarkan oleh Pengadilan Agama Bima dengan Nomor 603/Pdt.G/2019/PA.Bm. Putusan hakim Pengadilan Agama Bima tersebut merupakan salah satu putusan yang dirasakan tidak adil terutama oleh pihak tergutat/termohon (Istri) dalam kasus cerai talak yang disampaikan oleh penggugat/pemohon (suami). Termohon dalam gugatan rekonvensi telah menyampaikan secera secara tertulis kepada majelis yang berkaitan 
dengan haknya sebagai seorang istri apabila secara resmi bercerai. Adapun hak-hak yang diminta tersebut adalah Uang belanja (nafkah lampau), Nafkah iddah, Nafkah Mut 'ah, dan Harta bersama.

Duduk perkara dalam kasus di atas adalah pada tanggal 06 Mei 2015 pemohon melangsungkan pernikahan yang di catat oleh pegawai pencatat nikah kantor urusan agama kecamatan bolo kabuputen Bima berdasarkan Kutipan Akta Nikah Nomor 76/09/V/2015. Setelah menikah mereka tinggal di Bolo selama 2 tahun, dan hidup bahagia layaknya suami istri.

Pada tahun 2017 terjadi pertengkaran hebat antara mereka, yang menyebabkan kehidupan rumah tangganya sudah tidak harmonis. Puncaknya pada tahun 2018 mereka pisah ranjang selama lebih kurang satu tahun. Walaupun pernah di damaikan oleh berbagai pihak namun upaya tersebut tidak berhasil untuk menyatukan mereka kembali. Kemudian pada akhirnya tahun 2019 suaminya menggugat cerai istrinya dipengadilan Agama Bima.

Atas permohonan perceraian yang dilayangkan oleh pemohon, termohon mengajukan jawaban secara tertulis kepada majelis hakim melalui kuasa hukumnya sekaligus mengajukan gugatan rekonvensi yang pada pokoknya berisi:

1. Uang belanja (nafkah bulanan) sebesar Rp. 5.000.000 perbulan

2. Nafkah iddah sebesar Rp. 70.000 .000

3. Mut 'ah sebesar Rp. 70.000 .000

4. Harta bersama berupa tanah dan rumahnya

Berdasarkan gugatan rekonvensi tersebut, tergugat rekonvensi/pemohon konvensi mengajukan jawaban sebagai berikut:

1. Uang belanja (nafkah bulanan) kesanggupannya Rp. 100.000/bulan

2. Nafkah iddah kesanggupannya Rp. 1.000 .000

3. Mut 'ah disanggupi Rp. 1.000 .000

4. Harta bersama berupa tanah dan rumahnya di akui oleh pemohon sebagai harta bersama yang masih ditempati oleh tergugat.

Dalam amar putusannya Pengadilan Agama Bima memutuskan bahwa:

1. Nafkah madiah (nafkah lampau) sebesar Rp. 5.100 .000

2. Nafkah iddah Rp. 6.000 .000

3. Mut 'ah sebesar Rp. 5.000 .000

4. Harta gono gini di bagi masing-masing setengah 
Dalam kajian tulisan ini, penulis mencoba menganalisis dari aspek aturan-aturan yang berkaitan dengan perceraian sebagaimana termuat dalam undang-undang perkawinan dan kompilasi hukum islam maupun aturan lain yang berkaitan dengan perceraian. Penulis juga ingin menggali lebih jauh bagaimanakah islam mengatur tentang hal-hal sebagaimana termuat dalam gugatan konvensi dan rekonvensi yang disampaikan penggugat dan tergugat kepada majelis hakim Pengadilan Agama Bima.

\section{KERANGKA TEORITIS DAN PENGEMBANGAN HIPOTESIS}

\section{Pengadilan Agama}

Menurut Undang-Undang Republik Indonesia Nomor 7 Tahun 1989 Tentang Peradilan Agama mendefiniskan bahwa Peradilan Agama adalah peradilan bagi orang-orang yang beragama Islam. Dalam artian bahwa pengadilan agama adalah lembaga Negara dibidang peradilan yang hanya memiliki tugas untuk menyelesaikan segala bentuk sengketa perdata dalam umat islam.

Sementara tugas dan kewenangan pengadilan agama sebagaiman termuat dalam Pasal 49 ayat (1) menjelaskan bahwa "Pengadilan Agama bertugas dan berwenang memeriksa, memutus, dan menyelesaikan perkara-perkara di tingkat pertama antara orang-orang yang beragama Islam di bidang: a. perkawinan; b. kewarisan, wasiat, dan hibah, yang dilakukan berdasarkan hukum Islam; c. wakaf dan shadaqah."

\section{Perceraian}

Perceraian merupakan batalnya ikatan pernikahan antara pasangan suami istri akibat tidak adanya kecocokan. Dalam kamus besar bahasa Indonesia Perceraian asal katanya dari kata cerai yang mendapat awalan 'per' dan akhiran 'an'. Cerai artinya pisah atau putus hubungan sebagai suami istri.

Secara syar ' $\mathrm{i}$ perceraian berasal dari bahasa arab yaitu Talaq. Talaq memiliki arti melepaskan atau meninggalkan. Dalam konteks ini talaq berarti melepaskan ikatan perkawinan antara suami dan istri. Menurut Syaikh Kamil Muhammad Uwaidah Thalaq secara bahasa berarti pemutusan ikatan. Sedangkan secara istilah thalaq berarti pemutusan tali perkawinan.

Thalaq menurut jumlahnya terbagi dalam dua jenis yaitu thalaq Raj ' $i$ dan thalaq Ba 'in. Thalaq Raj' $i$ adalah thalaq yang lakukan oleh suami yang sudah digauli dengan thalaq satu maupun dua yang 
memungkinkannya untuk merujuk kembali sebelum berakhirnya masa Iddah. Sedangkan thalaq ba'in adalah thalaq yang memutuskan tali pernikahan antara suami dan istri secara total. Thala ba'in terbagi menjadi dua bentuk yaitu thalaq bain shugra dan thalaq bain qubra. thalaq bain shugra adalah thalaq satu atau dua yang dijatuhkan oleh suami kepada istri nya dengan tidak merujuk sampai berakhir masa iddahnya. Bila seorang suami ingin merujuknya kembali maka dia harus melalui mahar dan akad kembali. Sedangkan thalaq bain kubra adalah thalaq tiga, yang menyebabkan putusnya tali perkawinan untuk selamanya. Pada kondisi ini suami tersebut boleh menikahinya kembali apabila sudah dinikahi dan disetubuhi oleh orang lain. ${ }^{1}$

Menurut hukumnya thalaq terbagi dua yaitu thalaq sunnah (sunni) dan thalaq bid 'ah. Thalaq sunnah adalah thalaq yang di jatuhkan oleh suami kepada istrinya sesudah di gauli dengan thalaq satu dalam kondisi suci yang belum di gauli. Ketentuan mengenai thalak sunnah ini sesuai dengan penjelasan pada thalaq raj'i dan thalaq bain. Sedangkan thalaq bid 'ah adalah thalaq yang menyalahi sunnah baik dari segi waktu (Istri sedang haid, nifas dan sudah digauli pada saat dia suci) maupun dari segi bilangan (suami mentalaq tiga sekaligus dalam waktu maupun tempat yang sama $)^{2}$.

Menurut subyeknya thalaq dibagi yaitu thalak dan khuluk. Thalaq adalah perceraian yang terjadi atas keinginan suami. Khuluk adalah perceraian yang terjadi atas permintaan isteri dengan memberikan tebusan atau iwadl kepada suami dan atas persetujuan suaminya. ${ }^{3}$

\section{Gugatan Rekonvensi dan Gugatan Konvensi}

Menurut M. Yahya Harahap dalam buku Hukum Acara Perdata tentang Gugatan, Persidangan, Penyitaan, Pembuktian, dan Putusan Pengadilan (hal. 468) istilah (gugatan) rekonvensi diatur dalam Pasal 132a HIR yang maknanya rekonvensi adalah gugatan yang diajukan tergugat sebagai gugatan balasan terhadap gugatan yang diajukan penggugat kepadanya. Dalam penjelasan Pasal 132a HIR disebutkan, oleh karena bagi tergugat diberi kesempatan untuk mengajukan gugatan melawan, artinya. untuk menggugat kembali penggugat, maka tergugat itu tidak perlu

\footnotetext{
${ }^{1}$ Syaihk Muhammad Bin Ibrahim Bin Abdullah At-Tuwaijiri, 2012. Eksiklopedi Islam: al Kamil, Darussunnah, Jakarta. Hal. 1059-1060

2 Ibid, Hal. 1057-1058

${ }^{3}$ Kompilasi Hukum Islam
} 
mengajukan tuntutan baru, akan tetapi cukup dengan memajukan gugatan pembalasan itu bersama-sama dengan jawabannya terhadap gugatan lawannya. ${ }^{4}$

Istilah konvensi sebenarnya merupakan istilah untuk menyebut gugatan awal atau gugatan asli. Istilah ini memang jarang digunakan dibanding istilah gugatan karena istilah konvensi baru akan dipakai apabila ada rekonvensi (gugatan balik tergugat kepada penggugat). Di dalam penjelasan Yahya Harahap (hal. 470), Anda dapat menemukan bahwa ketika penggugat asal (A) digugat balik oleh tergugat (B) maka gugatan $A$ disebut gugatan konvensi dan gugatan balik $B$ disebut gugatan rekonvensi. $^{5}$

\section{Nafkah Madhiyah}

Nafkah madhiyah atau nafkah lampau adalah nafkah yang diberikan oleh suami kepada istrinya pada saat sebelum terjadinya perceraian secara syah oleh Pengadilan agama. Nafkah madliyah adalah kewajiban atas seseorang yang tidak dilakukan pada zaman lampau atau pada masa yang lalu.

Menurut Rendra Widyakso Nafkah madiyah adalah nafkah yang telah lampau tidak selalu dihubungkan dengan perkara cerai talak, yang kemudian dalam hal ini istri dapat mengajukan tuntutan nafkah madiyah saat suaminya mengajukan perkara cerai talak dengan mengajukan gugatan rekonvensi. ${ }^{6}$

\section{Nafkah Iddah}

Iddah adalah masa wanita menunggu dan menahan diri dari menikah setelah wafatnya suami atau perpisahan dengannya. Iddah hukumnya adalah wajib atas wanita jika terpenuhi sebab-sebabnya. Menurut Syaikh Uwaidah Iddah adalah masa dimana seorang wanita yang diceraikan suaminya menunggu. ${ }^{7}$

Nafkah iddah sebagai dasar pemikiran bahwa pada perkara cerai gugat adalah terjadinya fakta bahwa pasca putusan, mantan isteri menjalani massa iddah. Sehingga konsep nafkah iddah sebagaimana

\footnotetext{
${ }^{4}$ https://www. hukumonline.com/klinik/

${ }^{5} \mathrm{https}$ // www. hukumonline.com/klinik/

${ }^{6}$ Rendra Widyakso, 2019. Tuntutan Nafkah Dalam Perkara Cerai Gugat, Makalah Calon Hakim Magang pada Pengadilan Agama Semarang.

${ }^{7}$ Syaikh Kamil Muhammad Uwaidah, 2009. Fiqh Wanita Edisi Lengkap, Pustaka Al Kautsar, Jakarta. Hal.477
} 
dijelaskan dalam Al-Qur'an dijadikan illat yang sama terhadap perkara cerai talak. ${ }^{8}$

\section{Nafkah Mut`ah}

Mut'ah secara bahasa berarti kesenangan. Menurut madzhab syafi'i, mut'ah adalah nama yang digunakan untuk menyebut harta-benda yang wajib diberikan laki-laki (mantan suami) kepada perempuan (mantan isteri) karena ia menceraikannya. Mut'ah adalah nama untuk menyebut harta-benda yang wajib diberikan seorang (mantan) suami kepada (mantan) isterinya karena ia menceraikannya"9.

Kata mut'ah merupakan bentuk lain dari kata al-mata', yang berarti sesuatu yang dijadikan obyek bersenang-senang. Adapun yang dimaksud dengan mut'ah dalam beberapa ayat di atas ialah sesuatu yang diberikan oleh suami kepada istri yang diceraikannya sebagai penghibur. Secara eksplisit bahwa ayat di atas mewajibkan "kamu", maksudnya para suami untuk memberikan mut'ah kepada "mereka”, maksudnya kepada para istri yang ditalak. Hal ini menurut riwayat sejalan dengan pendapat mayoritas Ulama Hanafiyyah, sesungguhnya Imam Ahmad bin Hanbal berpendapat bahwa mut'ah itu wajib untuk semua istri yang ditalak. Sebagian Ulama Malikiyyah, seperti Ibnu Shihab berpendapat semua perempuan yang ditalak di manapun di muka bumi ini berhak mendapat mut'ah. Imam Syafi'i yang juga dipertegas oleh al-Syarbaini menyebutkan bahwa kebanyakan para sahabat yang diketahuinya, berdasarkan ayat di atas menegaskan bahwa yang berhak mendapat mut'ah adalah semua perempuan yang ditalak ${ }^{10}$.

Nafkah Mut 'ah adalah pemberian dari bekas suami kepada istrinya yang dijatuhi talak berupa uang atau benda lainnya. Al Baqarah (2) dan Surat Al-Ahzab (33) mengatakan "Dan hendaklah mereka kamu beri mut'ah bagi yang mampu menurut kemampuannya dan bagi yang tidak mampu menurut kesanggupannya, yaitu pemberian dengan cara yang patut, yang merupakan kewajiban bagi orang-orang yang berbuat kebaikan".

Nafkah mut'ah konsepnya adalah istri yang dicerai merasa menderita karena harus berpisah dengan suaminya. Guna meminimalisir

\footnotetext{
${ }^{8}$ Rendra Widyakso, Op.Cit

${ }^{9}$ Zakariya al-Anshari, Asna al-Mathalib Syarhu Raudl ath-Thalib, Bairut-Dar al-Kutub alIlmiyyah, Cet Ke-1, 1422 H/2000 M, Juz 3. Hal. 319

${ }^{10}$ https:// www.pta-banten.go.id/artikel-pengadilan/736-kewajiban-mut-ah-dan-nafkahiddah-keadilan-bayang-bayang-semu
} 
penderitaan atau rasa sedih tersebut, maka diwajibkanlah bagi mantan suami untuk memberikan nafkah mut"ah sebagai penghilang pilu. Namun beberapa pendapat menyatakan bahwa apabila yang mengajukan adalah istri yakni dalam perkara cerai gugat, maka nafkah mut'ah dianggap tidak ada. Dengan melihat tidak adanya derita yang dialami oleh istri ${ }^{11}$.

\section{Harta Bersama / Gono Gini}

Baik di Undang-Undang No.1 Tahun 1974 tentang perkawinan maupun di dalam Kompilasi Hukum Islam tidak terdapat devinisi yang jelas mengenai harta bersama atau gono gini. Tetapi dalam dua peraturan tersebut dapat dimaknai bahwa harta bersama adalah harta yang didapat oleh suami dan istri selama dalam ikatan pernikahan.

Pada Pasal 91 (1) Kompilasi Hukum Islam menjelaskan bahwa "Harta bersama sebagaimana tersebut dalam pasal 85 di atas dapat berupa benda berwujud atau tidak berwujud. (2) Harta bersama yang berwujud dapat meliputi benda tidak bergerak, benda bergerak dan surat-surat berharga. (3) Harta bersama yang tidak berwujud dapat berupa hak maupun kewajiban. (4) Harta bersama dapat dijadikan sebagai barang jaminan oleh salah satu pihak atas persetujuan pihak lainnya."

\section{METODE}

\section{Jenis Penelitian}

Jenis Penelitian yang di gunakan dalam penulisan skripsi ini adalah penelitian hukum Normatif. Jenis penelitian ini juga di sebut penelitian hukum yuridis. Menurut Marjuki penelitian hukum Normatif adalah suatu proses untuk menemukan suatu aturan hukum, prinsipprinsip hukum, maupun doktrin-doktrin hukum guna menjawab isu hukum yang dihadapi ${ }^{12}$.

\section{Pendekatan Yang Digunakan}

Pendekatan yang digunakan dalam penelitian ini adalah pendekatan pendekatan perundang-undangan. Pendekatan perundangundangan (Statue Approach) adalah pendekatan yang dilakukan dengan

\footnotetext{
${ }^{11}$ Rendra Widyakso, Loc.Cit

12 Bambang Waluyo, 2002. Jenelitain Hukum Dalam Praktek, Sinar Grafika. Jakarta. Hal.15
} 
menelaah semua undang-undang dan regulasi yang bersangkut paut dengan isu hukum yang sedang ditangani/diteliti ${ }^{13}$.

\section{Sumber Data dan Jenis}

\section{a. Sumber Data}

Dalam penulisan skripsi ini, sumber data yang dipergunakan ada 2 (dua) jenis yaitu ${ }^{14}$ :

1). Data Primer

Data primer adalah data yang diperoleh langsung pada subyek penelitian. Mengacu pada pengertian tersebut di atas, data primer yang dimaksud dalam penelitian ini berdasarkan dari hasil wawancara dengan obyek penelitian yang akan diambil pada daerah penelitian.

2). Data sekunder

Data sekunder adalah data pendukung. Data ini diperoleh berdasarkan hasil studi kepustakaan, baik yang bersumber dari para pakar hukum, buku-buku, kamus, jurnal penelitian maupun dari beberapa rumusan peraturan perundang-undangan yang berlaku.

\section{b. Jenis Data}

Dalam penelitian skripsi ini jenis data lazimnya dibedakan antara jenis data primer, sekunder dan tersier. Karena sumber datanya adalah sumber data sekunder maka jenis data yang digunakan adalah jenis data sekunder. Sumber data sekunder menggunakan 3 bahan hukum yaitu: ${ }^{15}$

1) Bahan hukum primer

Mukti Fajar dan Yulianto Achmad menjelaskan bahan hukum primer adalah bahan hukum yang bersifat autoritatif artinya mempunyai otoritas, yaitu merupakan hasil dari tindakan atau kegiatan yang dilakukan oleh lembaga yang berwenang untuk itu ${ }^{16}$.

2) Bahan hukum sekunder

Bahan hukum sekunder yaitu bahan hukum yang dapat memberikan

\footnotetext{
${ }^{13}$ Peter Mahmud Marzuji, 2012. Metode Penelitian Hukum, Kencana Prenada Media Group, Jakarta. Hal. 34

${ }^{14}$ Soerjono Sukanto, 2012, Pengantar Penelitian Hukum, Rineke Cipta, Jakarta. Hal. 51

${ }^{15}$ Soerjono Sukanto, Ibid. Hal. 11

${ }^{16}$ Mukti Fajar \& Yulianto Achmad, 2010, Dualisme Penelitian Hukum Normatif \& Empiris, Yogyakarta, Pustaka Pelajar. Hal.157.
} 
penjelasan terhadap bahan hukum primer. Bahan hukum sekunder dapat berupa; 1) Buku-buku Hukum dan ilmiah yang berkaitan dengan permasalahan yang akan diteliti. 2) Jurnal-jurnal Hukum dan sosial yang berkaitan dengan permasalahan yang akanditeliti. 3) Hasil Penelitian yang berkaitan dengan permasalahan yang akan diteliti. 4) Makalah-makalah, artikel-artikel, dan karya tulis yang berkaitan dengan permasalahan yang akan diteliti. 5) Internet yang berkaitan dengan permasalahan yang akan diteliti.

3) Bahan hukum tersier

Bahan hukum tersier yaitu, bahan hukum yang memberikan petunjuk merupakan penjelasan terhadap bahan hukum primer dan skunder yang terdiri dari: 1) Kamus Hukum. 2) Kamus Bahasa Indonesia.

\section{Tehnik Pengumpulan Data}

Tehnik Pengumpulan Data yang digunakan pada penelitian ini berupa:

a. Dokumentasi adalah suatu metode pengumpulan data dan pencatatan terhadap berkas-berkas atau dokumnen yang ada hubungannya dengan materi yang dibahas. Menurut Suharsimi dokumentasi berasal dari kata dokumen, yang artinya barang-barang tertulis. ${ }^{17}$ Dokumentasi ini bisa berupa hasil putusan pengadilan.

b. Kepustakaan

Salah satu jenis penelitian bila dilihat dari tempat pengambilan data adalah penelitian kepustkanaan (library research). Disebut penellitian kepustakaan karena data-data atau bahan-bahan yang diperlukan dalam menyelesaikan penelitian tersebut berasal dari kepustakaan baik berupa buku-buku, ensiklopedi, kamus, jurnal, dokumen, majalah dan lain sebagainya. ${ }^{18}$

\section{Teknik Analisa Data}

Adapun teknik analisa data yang digunakan dalam penelitian ini adalah analisis preskriptif. Menurut Peter Mahmud analisis preskriptif digunakan untuk memberikan rekomendasi aksi yang diperkirakan akan

\footnotetext{
${ }^{17}$ Suharsimi Arikunto, 1991. Prosedur Penelitian, Suatu Pendekatan Praktek, Rineke Cipta, Jogjakarta. Hal. 131

${ }^{18}$ Nursapia Harahap, 2014, Penelitian Kepustakaan. Jurnal Iqra` Volume 08 Nomor 01
} 
memaksimalkan pencapaian tujuan yang kita inginkan. ${ }^{19}$ Analisis Preskriptif digunakan oleh penulis untuk memberikan gambaran yang jelas bagaimana isi gugatan tersebut dalam konteks syariat islam dan hukum positif.

\section{HASIL DAN PEMBAHASAN}

\section{Nafkah Madhiyah}

Nafkah madhiyah sebagaimana yang sudah dijelaskan dalam tinjuan teori di atas adalah nafkah lampau yang diberikan oleh suami kepada istrinya. Secara spesifik istilah nafkah madhiyah tidak ditemukan dalam Undang-undang No. 1 Tahun 1974 tentang Perkawinan. Pasal yang mengatur tentang madhiyah lebih dengan termuat pada Bab VIII tentang Putusnya Perkawinan Serta Akibatnya pasal 42. Dalam pasal tersebut dijelaskan pada point "b" dan "c" mengatakan bahwa "Bapak yang bertanggung jawab atas semua biaya pemeliharaan dan pendidikan yang diperlukan anak itu, bilamana bapak dalam kenyataannya tidak dapt memberi kewajiban tersebut pengadilan dapat menentukan bahwa ikut memikul biaya tersebut" dan "Pengadilan dapat mewajibkan kepada bekas suami untuk memberikan biaya penghidupan dan/atau menentukan sesuatu kewajiban bagi bekas isteri".

Kompilasi Hukum Islam Pasal 136 ayat 1 dan 2 menjelaskan "Selama berlangsungya gugatan perceraian atas permohonan penggugat atau tergugatberdasarkan pertimbangan bahaya yang mingkin ditimbulkan, Penghadilan Agama dapatmengizinkan suami isteri tersebut untuk tidak tinggal dalam satu rumah. Selama berlangsungnya gugatan perceraian atas permohonan penggugat atau tergugat,Pengadilan Agama dapat: a. menentukan nafkah yang harus ditanggung oleh suami; b. menentukan hal-hal yang perlu untuk menjamin terpeliharanya barang-barang yang menjadihak bersama suami isteri atau barang-barang yang menjadi hak suami atau barang-barang yang menjadi hak isteri."

Pasal 149 dikatakan "Bilamana perkawinan putus karena talak, maka bekas suami wajib: a. memberikan mut 'ah yang layak kepada bekas isterinya, baik berupa uang atau benda, kecuali bekas isteri tersebut qobla al dukhul; b. memberi nafkah, maskan dan kiswah kepada bekas isteri selama dalam iddah, kecuali bekas isteri telah di jatuhi talak ba'in atau nusyuz dan dalam keadaan tidak hamil; c. melunasi mahar yang

${ }^{19}$ Peter Mahmud, Op.Cit. Hal. 83 
masih terhutang seluruhnya, dan separoh apabila qobla al dukhul; d. memberikan biaya hadhanah untuk anak-anaknya yang belum mencapai umur 21 tahun."

Dari pasal 149 tersebut jelas bahwa nafkah madiyah tidak termuat dalam peraturan perundang-undangan yang berlaku baik UU Nomor 1 Tahun1974 tentang perkawinan maupun Kompilasi Hukum Islam. Hal ini tentu putusan menjadi aneh disebabkan dasar hukum hakim $m$ memutus hal tersebut tidak ada dalam undang-undang. Hal ini hanya di atur dalam SEMA Nomor 3 Tahun 2017 yang hanya memuat satu kalimat bahwa nafkah madiyah bisa dijadikan pertimbangan bagi hakim untuk memutuskan perkara perceraian.

Kedudukan nafkah madhiyah sesungguhnya tidak termuat secara eksplisit dalam peraturan perundangan baik Undang-Undang perkawinan maupun kompilasi hukum islam. Tidak termuatnya nafkah madhiyah ini sesungguhnya bukan tanpa alasan. Karena merujuk pada al Quran dan Sunnah sesungguhnya yang menjadi kewajiban bagi suami hanya memberikan nafkah iddah dan mut ah kepada istrinya yang secara syar ' $\mathbf{i}$ masih diharapkan untuk dirujuk oleh suaminya selama 3 kali quru/3 kali haid.

Dalam konteks ini nafkah madhiyah kalau dikaitkan dengan proses perceraian, maka dapat dilihat dari dua hal. Pertama, kalau suami meninggalkan istrinya tanpa alasan dan tanpa ikrar thalaq dalam waktu tertentu maka, pada konteks ini berlaku nafkah madhiyah (nafkah karena penelantaran) sebab istri yang ditinggalkan tanpa ikrar thalaq sudah tentu masih syah sebagai istrinya dan suami memiliki kewajiban untuk memberikan nafkah baik lahir maupun batin.

Kedua, kalau suami meninggalkan istri dengan ikrar thalaq yang jelas misalnya "aku telah menceraikan kamu dan saya akan keluar dari rumah ini”, maka secara syar'i sesungguhnya perceraian itu telah syah secara syar'i. Dan suami yang meninggalkan rumah dengan ikrar thalaq tersebut tentu tidak berkewajiban untuk membayar nafkah madhiyah. Tetapi hanya dibebankan biaya nafkah iddah dan mut 'ah serta hadhanah (kalau mereka memiliki anak) yang tentu berdasarkan pada kesanggupan suami.

Kendati Putusan hakim ini berpedoman SEMA Nomor 3 Tahun 2018 dalam Rumusan Hukum Kamar Agama Terkait Hukum Keluarga menjelaskan bahwa "Hakim dalam menetapkan Nafkah madhiyah, Nafkah Iddah, Mut 'ah dan nafkah anak harus mempertimbangkan rasa keadilan 
dan kepatutan dengan menggali fakta kemampuan ekonomi suami dan fakta kebutuhan dasar hidup istri dan/anak.

Kalau dilihat dalam konteks kasus tersebut, dalam uraian duduk perkaranya pemohon menjelaskan bahwa termohon dan orang tua termohon sering mengusir pemohon dari rumahnya sendiri, yang menyebakan suaminya merasa kepemimpinan dalam keluarga sudah tidak dihargai. Sehingga, tidaklah elok sesungguhnya bagi seorang istri menuntut nafkah lampau disebabkan karena tindaknnya tersebut. Majelis hakim sesungguhnya harus mempertimbangkan keadaan tersebut dalam putusannya. Sehingga, bagi pemohon putusan tersebut mencermin keadilan substansial.

Oleh karena itu, paling tidak ada tiga alasan mengapa putusan ini cacat secara hukum syar'i. Pertama, merupakan fakta bahwa kepergian suami meninggalkan rumah karena di usir oleh istri dan orangtuanya. Kedua, adanya ikrar talaq pada saat meninggalkan rumah dan ketiga tidak terdapatnya isi gugatan rekonvensi terkait nafkah madhiyah menjadi alasan yang cukup kuat bahwa nafkah madhiyah tidak harus dikabulkan oleh hakim. Hal ini sesuai dengan Hadits yang diriwayatkan oleh Abu Hurairah Ra. Rasulullah Saw bersabda "ada tiga perkara baik dilakukan dengan sungguh-sungguh atau dengan bergurau maka dianggap syah yakni; nikah, thalaq dan rujuk".

Apalagi dalam gugatan rekonvensi yang disampaikan oleh termohon tidak memasukan dalam tuntutannya terkait dengan nafkah Madhiyah. Yang dituntut adalah uang belanja bulanan, nafkah iddah, mut 'ah dan harta bersama. Sementara uang belanja bulanan yang menjadi tuntutan pertama tidak di masukan dalam amar putusan. Hakim agama dalam konteks ini telah melakukan abuse of power, telah menyalahi kewenangannya.

Putusan yang menyalahi tuntutan atau biasa disebut dengan asas ultra petita adalah hakim memutuskan perkara yang tidak dituntut/dimohonkan lebih dari yang dimintakan. Karena putusan terkait dengan nafkah madhiyah tidak terdapat dalam gugatan rekonvensi yang disampaikan oleh termohon maka dengan sendirinya putusan tersebut batal demi hukum.

\section{Nafkah Iddah}

Iddah sebagaimana yang dijelaskan di atas adalah masa dimana seorang wanita yang diceraikan suaminya menunggu untuk menikah lagi. 
Pada masa menunggu tersebut istri tidak boleh menerima lamaran orang lain. Hal ini sesuai dengan firman Allah dalam Quran Surat Al Baqarah: 228 yang artinya "Wanita-wanita yang ditalak handaklah menahan diri (menunggu) tiga kali quru'. Tidak boleh mereka menyembunyikan apa yang diciptakan Allah dalam rahimnya, jika mereka beriman kepada Allah dan hari akhirat. Dan suami-suaminya berhak merujukinya dalam masa menanti itu, jika mereka (para suami) menghendaki ishlah. Dan para wanita mempunyai hak yang seimbang dengan kewajibannya menurut cara yang ma'ruf. Akan tetapi para suami, mempunyai satu tingkatan kelebihan daripada isterinya. Dan Allah Maha Perkasa lagi Maha Bijaksana". Quru 'di sini sebagaimana sabda Rasulullah saw "dia beriddah selama tiga kali masa haid" (HR. Ibnu Majah). ${ }^{20}$

Dalam hukum islam memberikan nafkah iddah kepada istri merupakan kewajiban yang dibebankan kepada suami. Selama masa itu suami harus menjamin kebutuhan istri sebagaimana layaknya. Dalam konteks ini pemberian nafkah iddah ini sesungguhnya ketika istri yang dalam masa menunggunya tidak berada dirumah suaminya.

Dalam Surat Athalaq: 1 Allah Swt mengatakan "Hai Nabi, apabila kamu menceraikan isteri-isterimu maka hendaklah kamu ceraikan mereka pada waktu mereka dapat (menghadapi) iddahnya (yang wajar) dan hitunglah waktu iddah itu serta bertakwalah kepada Allah Tuhanmu. Janganlah kamu keluarkan mereka dari rumah mereka dan janganlah mereka (diizinkan) ke luar kecuali mereka mengerjakan perbuatan keji yang terang. Itulah hukum-hukum Allah dan barangsiapa yang melanggar hukum-hukum Allah, maka sesungguhnya dia telah berbuat zalim terhadap dirinya sendiri. Kamu tidak mengetahui barangkali Allah mengadakan sesudah itu sesuatu hal yang baru." (Atthalaq : 1)

Quraish Shihab Dalam Tafsir online terhadap ayat ini ${ }^{21}$ menjelaskan bahwa surat ini membicarakan beberapa hukum talak dan idah ('iddah) dengan berbagai jenis dan hukumnya. Di antaranya adalah, misalnya, orang yang sedang dalam masa iddah harus tetap tinggal di rumah tempat ia dijatuhi talak, kewajiban suami memberi nafkah dan tempat tinggal kepadanya, dan sebagainya. Di sela-sela pembicaraan tentang beberapa hukum di atas, seperti umumnya cara yang digunakan di dalam al-Qur'ân, Allah memberikan janji kepada orang yang melaksanakan segala perintahNya dan ancaman kepada orang yang melanggar ketentuan-Nya.

\footnotetext{
20 Ibid, Hal. 477

${ }^{21}$ https://tafsirq.com/65-at-talaq/ayat-1
} 
Disinggung pula akibat yang diterima oleh orang-orang yang enggan melaksanakan perintah Allah dan Rasul-Nya. Surat ini ditutup dengan anjuran kepada orang-orang Mukmin untuk senantiasa bertakwa, peringatan kepada mereka akan karunia pengutusan rasul yang membacakan ayat-ayat Allah untuk mengeluarkan mereka dari kegelapan menuju cahaya dan penjelasan tentang kekuasaan Allah yang besar dalam menciptakan tujuh langit dan, seperti itu pula, bumi. Wahai Nabi, jika kamu hendak menjatuhkan talak kepada istri-istrimu maka jatuhkanlah talak itu ketika mereka sedang dalam keadaan suci yang tidak dicampuri. Tepatkanlah hitungan masa idah dan bertakwalah kepada Tuhanmu. Jangan izinkan istri-istri yang kamu jatuhi talak itu keluar dari tempat mereka ditalak. Jangan izinkan mereka keluar kecuali jika melakukan perbuatan keji yang sangat nyata. Ketentuan- ketentuan itu merupakan hukum yang telah ditetapkan oleh Allah untuk para hamba-Nya. Barangsiapa yang melanggar ketentuan Allah maka sesungguhnya ia telah menzalimi diri sendiri. Kamu, hai orang yang melanggar, tidak mengetahui barangkali Allah akan mewujudkan sesuatu yang tidak diperkirakan, sesudah talak itu, sehingga kedua pasangan suami-istri itu kembali saling mencintai (Tafsir al Misbah, Qurais shihab).

Sedangkan Jalalain menjelaskan "Hai Nabi” makna yang dimaksud ialah umatnya, pengertian ini disimpulkan dari ayat selanjutnya. Atau makna yang dimaksud ialah, katakanlah kepada mereka (apabila kalian menceraikan istri-istri kalian) apabila kalian hendak menjatuhkan talak kepada mereka (maka hendaklah kalian ceraikan mereka pada waktu mereka menghadapi idahnya) yaitu pada permulaan idah, seumpamanya kamu menjatuhkan talak kepadanya sewaktu ia dalam keadaan suci dan kamu belum menggaulinya. Pengertian ini berdasarkan penafsiran dari Rasulullah saw. sendiri menyangkut masalah ini; demikianlah menurut hadis yang telah diriwayatkan oleh Bukhari dan Muslim (dan hitunglah waktu idahnya) artinya jagalah waktu idahnya supaya kalian dapat merujukinya sebelum waktu idah itu habis (serta bertakwalah kepada Allah Rabb kalian) taatlah kalian kepada perintah-Nya dan larangan-Nya. (Janganlah kalian keluarkan mereka dari rumah mereka dan janganlah mereka diizinkan keluar) dari rumahnya sebelum idahnya habis (kecuali kalau mereka mengerjakan perbuatan keji) yakni zina (yang terang) dapat dibaca mubayyinah, artinya terang, juga dapat dibaca mubayyanah, artinya dapat dibuktikan. Maka bila ia melakukan hal tersebut dengan dapat dibuktikan atau ia melakukannya secara jelas, maka ia harus 
dikeluarkan untuk menjalani hukuman hudud. (Itulah) yakni hal-hal yang telah disebutkan itu (hukum-hukum Allah dan barang siapa yang melanggar hukum-hukum Allah, maka sesungguhnya dia telah berbuat aniaya terhadap dirinya sendiri. Kamu tidak mengetahui barangkali Allah mengadakan sesudah itu) sesudah perceraian itu (sesuatu hal yang baru) yaitu rujuk kembali dengan istri yang telah dicerainya, jika talak yang dijatuhkannya itu baru sekali atau dua kali. ${ }^{22}$

Dari penjelasan kedua ahli tafsir di atas jelaslah bahwa ketentuan tentang nafkah iddah yang menjadi kewajiban bagi suami terhadap istrinya pada saat masa menunggu, itu terjadi ketika istri masih tinggal serumah dengan suami. Hal ini dilakukan dengan harapan agar pada suatu saat, suami dan istri ini kembali menjalin hubungan dan membina rumah tangga sesuai dengan yang diperintahkan oleh Allah. Baik karena mereka melakukan hubungan suami istri ada saat masa iddah maupun kembali secara lisan yang tersampaikan kepada istinya. Kendati demikian walaupun istri misalnya selama masa iddah itu tinggal di rumah orangtuanya tetap suami memiliki kewajiban untuk memberikan nafkah iddah kepada istrinya selama 3 masa haid/ atau tiga bulan berturut-turut.

\section{Nafkah Mut `ah}

Pada surat edaran Mahkamah Agung Nomor 7 tahun 2012 pada bagian Hukum Keluarga menjelaskan bahwa kriteria penentuan besaran mut'ah, nafkah iddah dan nafkah anak adalah dengan mempertimbangkan kemampuan suami dan kepatutan, seperti lamanya masa perkawinan dan besaran take home pay suami.

Allah SWT memberi isyarat dalam Al-Qur'an Surat Al-Baqarah (2) ayat 231 “... atau ceraikan mereka dengan ma'ruf (baik)...”. Salah satu indikasi perceraian dilakukan dengan "ma'ruf (baik)" adalah memenuhi kewajiban mut'ah dan nafkah iddah yang memang merupakan hak bagi istri yang dicerai (ditalak) suaminya ${ }^{23}$. Mut ah adalah pemberian untuk menyenangkan hati istri yang diceraikan sebelum dicampuri. Hal ini juga termuat dalam QS Al Ahzab: 49 yang artinya "Wahai orang orang yang beriman, apabila kalian menikahi wanita-wanita yang beriman, kemudian kalian hendak menceraikan mereka sebelum kalian mencampurinya, maka sekali-sekali tidak wajib atas mereka iddah bagi

\footnotetext{
${ }^{22}$ https://tafsirq.com/65-at-talaq/ayat-1

${ }^{23}$ https: / / www.dar-alifta.org/ViewFatwa. aspx?ID=2266\&LangID=5\&MuftiType=2
} 
kalian yang kalian minta menyempurnakannya. Maka berikanlah mereka mut 'ah dan lepaskanlah mereka itu dengan cara yang sebaik-baiknya".

Kalau dilihat dalam konteks Surat Al Ahzab: 49 tersebut sudah jelas sesungguhnya bahwa yang dimaksud dengan mut'ah adalah pemberian secara sukarela kepada istri yang belum "dicampuri". Itulah kemudian apabila suami sudah memberikan mahar kepada istrinya tersebut diperbolehkan untuk mengambil setengah dari mahar yang diberikan.

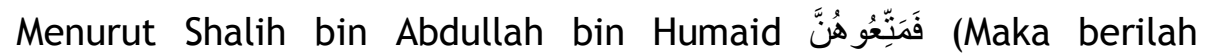
mereka mut'ah) Wanita yang diceraikan sebelum dicampuri namun telah ditentukan jumlah maharnya maka ia berhak mendapat setengah dari mahar itu. Dan jika belum ditentukan jumlah maharnya maka ia berhak mendapat mut'ah sesuai dengan ayat ini. Adapun wanita yang ditinggal mati suaminya apabila mati setelah selesai mengucapkan akad pernikahan dengannya dan belum mencampurinya maka kematiannya ini sama hukumnya dengan orang yang telah mencampuri istrinya, sehingga wanita ini harus melewati masa 'iddah selama empat bulan sepuluh hari berdasarkan ijma' para ulama ${ }^{24}$.

Sementara Muhammad bin Shalih asy-Syawi Ayat ini juga menunjukkan, bahwa wanita yang ditalak sebelum dicampuri diberi mut'ah sesuai kemampuan suami, tentunya hal ini apabila si suami belum menentukan mahar, jika sudah menentukan, maka apabila si suami menalaknya sebelum dukhul, ia berikan setengah mahar, dan hal itu sudah cukup tanpa perlu memberi mut'ah lagi. Demikian pula menunjukkan bahwa sepatutnya orang yang mencerai istrinya sebelum dukhul atau setelahnya berpisahnya dengan cara yang baik dan terpuji, karena jika tidak demikian akan ada keburukan yang timbul yaitu saling cela-mencela. ${ }^{25}$

Dengan demikian mut'ah di sini merupakan pemberian untuk menyenangkan hati istri yang diceraikan sebelum dicampuri. Tentunya hal ini jika si suami belum menyebutkan maharnya, jika sudah, maka untuknya setengah dari mahar yang disebutkan, demikian yang dikatakan Ibnu Abbas, dan itulah yang dipegang oleh Imam Syafi'i.

Jika yang meminta talak adalah istri dan ia menggugurkan hakhaknya yang masih menjadi tanggungan suaminya, maka hak nafkah untuknya selama masa iddah, nafkah mut'ah dan mahar yang belum

\footnotetext{
${ }^{24}$ Marwan Hadidi bin Musa, Tafsir Online (https://tafsirweb.com/7661-quran-surat-alahzab-ayat-49.html)

${ }^{25} \mathrm{Ibib}$, Marwan Hadidi bin Musa, Tafsir Online.
} 
dibayarkan pun menjadi gugur, baik keseluruhan maupun sebagiannya. Allah berfirman:

"Tidak halal bagi kamu mengambil kembali sesuatu dari yang telah kamu berikan kepada mereka, kecuali kalau keduanya khawatir tidak akan dapat menjalankan hukum-hukum Allah. Jika kamu khawatir bahwa keduanya (suami-istri) tidak dapat menjalankan hukum-hukum Allah, maka tidak ada dosa atas keduanya tentang bayaran yang diberikan oleh istri untuk menebus dirinya. Itulah hukum-hukum Allah, maka janganlah kamu melanggarnya. Barangsiapa yang melanggar hukum-hukum Allah mereka itulah orang-orang yang zalim". (Al-Baqarah: 229)

Hal penting yang harus diingat adalah bahwa perempuan yang dicerai berhak mendapatkan mut'ah apabila perceraian itu lahir dari inisatif pihak lelaki. Artinya, jika perceraian itu muncul inisiatif dari pihak perempuan, seperti dalam kasus faskh (cerai gugat) dimana pihak perempuan menggugat cerai suaminya dengan alasan suami tidak mampu menafkahinya atau menghilang. Atau disebabkan oleh pihak perempuan itu sendiri, seperti suami meminta cerai disebabkan oleh adanya aib pada isterinya, seperti isteri terkena penyakit kusta atau lepra.

Maka dalam hal ini ia tidak berhak mendapatkan mut'ah mengikuti

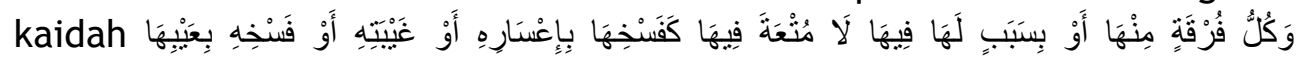
"Setiap perceraian yang terjadi karena inisiatif dari pihak perempuan atau disebabkan oleh pihak perempuan maka tidak ada mut'ah, seperti pihak perempuan menggugat cerai suaminya karena si suami tidak mampu mencukupi nafkahnya atau menghilang, atau pihak lelaki mengajukan tuntutan cerai karena adanya aib pada isterinya". ${ }^{26}$ Lebih lanjut dijelaskan oleh Muhyiddin Syarf Nawawi dalam kitab Raudlah athThalibin-nya bahwa jika seorang laki-laki menceraikan isterinya dan belum sempat disetubuhi (dukhul) maka harus dilihat terlebih dahulu. Sebagaimana kita ketahui bersama, bahwa perempuan yang dicerai sebelum disetubuhi maka ia hanya berhak mendapatkan separo dari maharnya. Maka apabila separo maharnya sudah diberikan, maka ia tidak wajib memberikan mut'ah kepada mantan isterinya. Namun jika separo maharnya belum diberikan, maka ia wajib memberikan mut'ah menurut pendapat yang masyhur di kalangan madzhab syafi'i. Sedangkan jika

\footnotetext{
${ }^{26}$ Taqiyuddin Muhamman Abu Bakar al-Husaini, 1999. Kifayah al-Akhyar, Damaskus-Dar alKhair, Juz, 1, Hal. 373 (dalam https://islam.nu.or.id/post/read/58444/hukum-

memberikan-mutrsquoah-setelah-perceraian)
} 
sudah disetubuhi, maka menurut qaul jadid yang al-azhhar, ia (perempuan yang diceraikannya) berhak mendapatkan mut'ah.

Adapun yang dimaksud dengan kewajiban ayah menanggung nafkah dalam ayat di atas adalah kewajiban suami selaku kepala rumah tangga untuk menafkahi istri bersama anak-anaknya selama dalam ikatan perkawinan, inklud kewajiban menafkahi bekas istri selama menjalani masa iddah bilamana terjadi perceraian antara suami dan istri. Kemudian mut'ah wajib diberikan oleh bekas suami dengan syarat belum ditetapkan mahar bagi istri ba'da al-dukhul ${ }^{27}$ dan perceraian atas kehendak suami ${ }^{28}$.

Dengan berdasarkan kajian terhadap dalil-dalil yang dikemukakan di atas dapat ditarik benang merah bahwa ketika perceraian terjadi sepasang suami istri, maka suami diperintahkan oleh Allah sebagaimana dalam surat Al Ahzab: 49 dan Al Baqarah: 229. Untuk memberikan mut 'ah kepada istrinya. Pemberian ini tergantung kepada kemampuan suami dan sifatnya bukan paksaan. Karena itu adalah pemberian untuk menyenangkan hati istri tersebut karena bercerai dengan suaminya.

\section{Harta Bersama / Gono Gini}

Surat Edaran Mahkamah Agung Nomor 7 tahun 2012 pada bagian Hukum Keluarga menjelaskan Gugatan harta bersama yang obyek sengketanya masih diagunkan sebagai jaminan utang atau obyek tersebut mengandung sengketa kepemilikan akibat transaksi kedua dan seterusnya, maka gugatan atas obyek tersebut harus dinyatakan tidak dapat diterima.

Surat edaran tersebut menjadi rujukan bagi para Hakim Pengadilan Agama untuk memutuskan perkara terkait dengan harta bersama. Merujuk pada putusan pengadilan Nomor 603/Pdt.G/2019/PA.Bm bahwa pemohon sebagai ASN memiliki hutang pada Bank NTB dan harus menjadi bahan petimbangan bagi hakim untuk memutus harta bersama yang menjadi gugatan rekonvensi yang dilayangkan oleh istrinya.

Harta bersama sebagaimana yang sudah dijelaskan pada teori di atas merujuk pada harta yang dihasilkan oleh suami dan istri pada saat menjalani biduk rumah tangga bersama. Ketentuan mengenai pembagian harta bersama susungguhnya bisa ditemukan baik dalam UU No.1 Tahun 1974 tentang Perkawinan maupun dalam kompilasi hukum Islam.

\footnotetext{
${ }^{27} \mathrm{Ba}$ 'da al Dukhul adalah perceraian (talak) yang dilakukan setelah terjadi proses akad nikah yang sah dimana isterinya tersebut ditalak setelah suaminya tersebut berhubungan badan sebagai suami isteri.

${ }^{28}$ Ibid, Taqiyuddin Muhamman Abu Bakar al-Husaini.
} 
Kompilasi Hukum Islam misalnya menjelaskan bahwa "Janda atau duda cerai hidup, masing-masing berhak seperdua dari harta bersama sepanjang tidak ditentukan lain dalam perjanjian perkawinan".

Dalam islam tidak ada nas yang menjelaskan secara eksplisit terkait dengan pembagian harta bersama. Sebab dalam islam suami kewajiban untuk memberikan nafkah kepada istri dan anak-anaknya baik lahir maupun batin. Hal ini bisa dilihat dalam hadits Rasulullah SAW. Berikut ini:

"Dari Hakim bin Mu'awiyah dari bapaknya berkata: Saya bertanya, "Ya Rasulullah apakah hak istri kami?" Beliau bersabda, "Engkau memberinya makan jika kamu makan, engkau memberinya pakaian jika kamu berpakaian." (HR. Ahmad, Abu Dawud, dan lainnya. AlIrwa': 2033) ${ }^{29}$.

Ketentuan negera yang termuat dalam kompilasi hukum islam dan syariat islam (Pendapat Fiqh para Ulama) sebenarnya saling bertentangan. Hal ini tentu menjadi masalah manakala ada terjadi ketika suami/istri lebih banyak bekerja untuk mengumpulkan harta sementara harta bersama itu harus dibagi sama rata. Menurut penulis paling tidak, kita harus melihatnya dalam 3 kondisi:

1. Apabila dapat dipastikan bahwa yang bekerja atau mencari kekayaan tersebut terdapat pada salah satunya (baik istri maupun suami) maka dalam hal ini tentu tidak bisa harta bersama tersebut dibagi masingmasing setengah. Tentu yang mendapatkan lebih banyak adalah yang lebih berkontribusi dalam memperoleh kekayaan tersebut.

2. Apabila secara jelas berdasarkan pengakuan saksi dan kenyataannya bahwa suami istri tersebut secara bersama-sama bekerja untuk mengumpulkan harta tersebut, maka dalam konteks inilah harta yang didapat selama ikatan pernikahan tersebut menjadi harta bersama dan dapat dibagi masing-masing setengan.

3. Terkadang ada suami atau istri yang hanya bekerja tapi tidak menambah harta yang dikumpulkan secara signifikan melainkan hanya dilakukan oleh salah satu pihak saja. Maka dalam konteks ini harta bersama tersebut tidak dapat dibagi secara merata melainkan harus dilebihkan kepada suami/istri yang memiliki andil lebih besar dalam mengumpulkan harta.

${ }^{29}$ https: / / konsultasisyariah.com/14448-teka-teki-harta-gono-gini.html 
Menurut Ahmad Syabiq mengutip hadits Dari Katsir bin Abdillah bin Amr bin Auf al-Muzani, dari bapaknya dari kakeknya, bahwa Rasulullah shallallahu 'alaihi wa sallam bersabda: "Berdamai itu boleh dilakukan antara kaum muslimin, kecuali sebuah perdamaian yang mengharamkan yang halal atau menghalalkan yang haram. Dan kaum muslimin itu tergantung pada syarat mereka, kecuali syarat yang mengharamkan yang halal atau menghalalkan yang haram." (HR. Tirmidzi no.1370, Ahmad 2:366, dan Abu Dawud no. 3594) $)^{30}$

Saat menerangkan hadis di atas, ash-Shan'ani berkata, "Para ulama telah membagi ash-shulh (perdamaian) menjadi beberapa macam: perdamaian antara muslim dan kafir, perdamaian antara suami dan istri, perdamaian antara kelompok yang bughat (zalim) dan kelompok yang adil, perdamaian antara dua orang yang mengadukan permasalahan kepada hakim, perdamaian dalam masalah tindak pelukaan seperti pemberian maaf untuk sanksi harta yang mestinya diberikan, dan perdamaian untuk memberikan sejumlah harta milik bersama dan hakhak. Pembagian inilah yang dimaksud di sini, yakni pembagian yang disebut oleh para ahli fiqih dengan ash-shulh (perdamaian). Dengan demikian berdasarkan dalil hadis Amr bin Auf al-Muzani di atas, jika suami istri berpisah dan hendak membagi harta bersama di antara mereka, dapat ditempuh jalan perdamaian (ash-shulh). Sebab, salah satu jenis perdamaian adalaah perdamaian antara suami istri, atau perdamaian tatkala ada persengketaan mengenai harta bersama. Dengan jalan perdamaian ini, pembagian harta gono-gini bergantung pada musyawarah antara suami istri. Bisa jadi suami mendapat $50 \%$ dan istri $50 \%$ atau suami mendapat 30\% dan istri 70\%, pun suami bisa mendapat 70\% dan istri $30 \%$, dan boleh pula pembagian dengan nisbah (prosentase) yang lain. Semuanya dibenarkan syara', selam merupakan hasil dari perdamaian yang telah ditempuh berdasarkan kerelaan masing-masing. ${ }^{31}$

\section{PENUTUP}

Diakhir tulisan ini, berdasarkan pada kajian terhadap dalil dan ketentuan perundang-perundangan maka dapat ditarik beberapa simpulan berikut:

1. Keputusan hakim terhadap gugatan perceraian konvensi dan rekonvensi dalam putusan tersebut di atas masih jauh dari

\footnotetext{
${ }^{30}$ Ahmad Sabiq, Lc (https: //konsultasisyariah.com/14448-teka-teki-harta-gono-gini.html) 31 Ibid, Ahmad Sabiq.
} 
ketentuan syariat islam yang sebenarnya. Walaupun di dasarkan pada undang-undang Nomor 1 Tahun 1974 dan Kompilasi Hukum Islam yang terkadang juga bertentangan ketentuan hukum islam.

2. Berkaitan dengan nafkah yang harus ditunaikan oleh pemohon/tergugat rekonvensi seperti nafkah madiyah, mut 'ah dan harta bersama. Nafkah madhiyah hanya diberikan ketika istri ditelantarkan selama masa iddah dan sudah tentu antara nafkah iddah dan nafkah madiyah (nafkah lampau) itu adalah satu kesatuan. Karena begitu masa iddah selesai maka selesai sudah tanggung jawab suami kepada istri, terkecuali bila mereka memiliki anak. Begitupun juga harta bersama, menurut ketentuan hukum islam harta yang didapat selama perkawinan itu besarnya ditentukan tetapi harus didasarkan pada kontribusi masing-masing suami istri dalam memperoleh harta. Semakin besar kontribusinya dalam memperoleh harta bersama maka semakin besar bagian harta yang diperoleh. 


\section{DAFTAR PUSTAKA}

\section{Buku}

Bambang Waluyo, 2002. Jenelitain Hukum Dalam Praktek, Sinar Grafika. Jakarta.

Kamil Muhammad Uwaidah, 2009. Fiqh Wanita Edisi Lengkap, Pustaka Al Kautsar, Jakarta.

Muhammad Bin Ibrahim Bin Abdullah At-Tuwaijiri, 2012. Eksiklopedi Islam: al Kamil, Darussunnah, Jakarta.

Mukti Fajar \& Yulianto Achmad, 2010, Dualisme Penelitian Hukum Normatif \& Empiris, Yogyakarta, Pustaka Pelajar.

Nursapia Harahap, 2014, Penelitian Kepustakaan. Jurnal Iqra 'Volume 08 Nomor 01

Peter Mahmud Marzuji, 2012. Metode Penelitian Hukum, Kencana Prenada Media Group, Jakarta.

Rendra Widyakso, 2019. Tuntutan Nafkah Dalam Perkara Cerai Gugat, Makalah Calon Hakim Magang pada Pengadilan Agama Semarang.

Soerjono Sukanto, 2012, Pengantar Penelitian Hukum, Rineke Cipta, Jakarta.

Suharsimi Arikunto, 1991. Prosedur Penelitian, Suatu Pendekatan Praktek, Rineke Cipta, Jogjakarta.

\section{Undang-Undang}

Undang-Undang Nomor 1 Tahun 1974 tentang Perkawinan

Inpres Nomor 1 tahun 1991 tentang Kompilasi Hukum Islam

Surat Edaran Mahkamah Agung Nomor 07 Tahun 2012

Peraturan Mahkamah Agung Nomor 3 tahun 2017 tentang Pedoman Mengadili Perkara Perempuan Berhadapan dengan hukum.

Surat Edaran Mahkamah Agung No. 03 Tahun 2018

Kompilasi Hukum Islam

\section{Website}

https: / /tafsirq.com/65-at-talaq/ayat-1

https://www.pta-banten.go.id/artikel-pengadilan/736-kewajiban-mut-

ah-dan-nafkah-iddah-keadilan-bayang-bayang-semu

https://www.hukumonline.com/klinik/ 